\title{
The Development of Learning Planning Book Based On Problem Solving on Students of Economic Education Study Program at Faculty of Economics in Medan State University
}

\author{
Charles Fransiscus Ambarita ${ }^{1 *}$, Pasca Dwi Putra ${ }^{2}$, Joko Suharianto ${ }^{3}$, Putri Kemala Dewi Lubis ${ }^{4}$ \\ Faculty of Economics, Medan State University, Medan, Indonesia ${ }^{1,2,3,4}$ \\ *charles.ambarita@yahoo.com
}

\begin{abstract}
The cause of low mastery of students in understanding the material of Learning Planning course is the lack of literature or references related to Learning Planning materials. The book used so far only contains theories without examples, assignments, and understanding to solve problems. To respond this, an optimization effort of the development of learning media is needed, especially the development of book. One of the optimization efforts that can be done is develop book based on problem solving. This method is considered effective to increase students mastery in mastering Learning Planning materials. Through the application of problem solving, students are required to learn actively so that students learning activities are more dominant than lecturers' activities in learning. This study aims are to produce valid, practical, and effective Learning Planning course book based on problem solving and publication in proceeding at international seminar and can become book for students. This study uses 4D models consisting of 4 main stages, namely: 1) define, 2) design, 3) develop, and 4) dessiminate. In this study, only carried out until the develop stage, while the desseminate stage was not carried out due to limited cost and time. The trial subject of the development of Learning Planning course book based on problem solving is the third semester students of the Economic Education study program in 2019/2020 at Faculty of Economics in Medan State University. The criteria used to choose the location and trial class is the condition of students in accordance with the needs of researchers where the class has never used book based on problem solving. The results of this study show that Learning Planning course book based on problem solving produced are valid, practical and effective. The value of the validity of book based on validators' assessment are $83.7 \%$ and the book can be categorized valid. The practicality value of book assessed by students are $81.57 \%$ and the book can be categorized as practical in the learning process.
\end{abstract}

Keywords: Problem Solving, Learning Planning Course, Book, Development.

\section{Introduction}

Higher Education is an important pillar in the development of a nation and and has a crucial role in improving human resources and competitiveness. Higher education in Indonesia is a national education subsystem that includes diploma, bachelor, master, specialist and 
doctoral programs organized by Higher Education. Higher Education is obliged to organize education, research and community service [1].

Medan State University is one of the Producing Institution of Educational Personnel that produces products in the form of teachers. The Faculty of Economics as an integral part of Medan State University also participates in the success of Medan State University's mission to answer challenge, opportunity, community guidance, and prepare professional and competitive teacher candidates.

The profile of graduates in the form of professional and competitive teachers can be achieved by enhancing students' intellectual abilities and leading to broad educational goals, useful, tangible, meaningful in preparing students to face future challenges especially the Industrial Revolution 4.0. The quality of learning can be seen from the understanding of learning that is from the results and the learning process carried out.

To answer these challenges, the development of learning needs to be done at the Department of Economic Education in Medan State University. One of the main highlights in the development of learning undertaken is to increase mastery of the Learning Planning course. Based on observation, the cause of the low mastery of students in understanding Learning Planning course material is allegedly due to lack of literature or references related to Learning Planning materials. Students only refer to the book that have been used by lecturers without any other learning resources. In addition, the existing book only contain theories without examples, assignments, and understanding to solve problem.

To respond this, an optimization effort of the development of learning media is needed, especially the development of book. One of the optimization efforts that can be done is develop book based on problem solving. This method is considered effective to increase students mastery in mastering Learning Planning materials. Problem solving is expected to give students a more meaningful learning experience, because it was developed to help students learn about solving problems that arise in their experiences.

Through the application of problem solving, students are required to learn actively so that students learning activities are more dominant than lecturers activities in learning. The development of book based on problem solving begins with the arrangement of materials that suit with the needs. In presenting the material is equipped with a problem and solving as example of question and discussion. And at the end of the material created a problem (in the form of question) and students are asked to complete solving (as an answer).

Based on the reality, it is important to develop Learning Planning course book based on problem solving among students of the Department of Economic Education, Faculty of Economics, Medan State University. This book was developed using simple language and easily understood by students, and arranged as interesting as possible that is interactive so that students can learn independently. This book is different from other books which are developed based on problem solving and are expected to provide solution for students who have difficulty in mastering Learning Planning materials.

\section{Teaching Materials}

Teaching materials occupy an important position in achieving learning objectives. This is in line with the opinion of Prastowo [2] which stated that teaching materials are all materials (both information, tools, and texts) that are arranged systematically that displays a complete figure of competencies that will be mastered by students and used in the learning process with the aim of planning and studying learning implementation.

Outlined, books consist of knowledge, skills, and attitudes that students must learn that are arranged systematically so that they can accumulatively achieve learning outcomes. The 
standard teaching function for lecturers is to direct student activities in the learning process as well as being a substance that must be elaborated to students, while for students, teaching material serves as a guide in the learning process and is a learning outcomes that must be achieved.

Books are the development of instructional design that emphasizes the principles adopted from theories and research findings about learning. The orientation of teaching materials is optimize learning activities to achieve learning outcomes. Therefore, teaching materials must be able to present learning material that is meaningful to students as learning subjects.

BSNP [3], explaining that the feasibility of books can be seen from four dimensions, namely: (1) the feasibility of content means that a good book should contain material that supports learning outcomes and has indicators namely material breadth, material depth, material completeness, and material accuracy; (2) the feasibility of presentation means that the presentation of books can be assessed from several sub-components and / or indicators such as presentation techniques, supporting presentation, consistency of presentation, and presentation of learning materials; (3) the feasibility of language means that books are written in terms and rules that are correct, clear, and in accordance with the conditions of the development of the reader. The indicators are the use of Indonesian language rules that are good and right, follow improved spelling rules, terminologies in accordance with the concepts being the subject, there are explanations for terms that are difficult or not common, the language used is simple, straightforward and easy to understand for students, and the language is adjusted with the level of student and communicative development and developing students' thinking skills; and (4) the feasibility of graphic means that books can be seen from aspects of book size, book skin design, and book content design

\section{Learning Planning Course}

Learning Planning course are the course in semester three and must be given to students at Faculty of Economics and the Department of Economic Education in Medan State University. The basic consideration of the distribution of courses in KKNI put out Learning Planning course in semester three so that students as prospective teachers are equipped with knowledge on how to plan learning correctly so that students are expected to become professional teachers later.

\section{Problem Solving Method}

Problem solving according to Sadirman, et al. [4] is a way of presenting learning material by making problems as a starting point for discussion to be analyzed and synthesized in an effort to find solutions or answers by students. Problem Solving is often called or also called the experimental method, reflective thinking method, or scientific method.

Thus, Problem solving is a learning method that seeks to discuss problems to find solutions or answers. As teaching methods, problem solving methods are very good for developing scientific attitudes in students. Children who are used to solving problems mean they are used to thinking at a high level. Conversely, higher order thinking is very necessary in solving various problems in life. Besides being trained in thinking, students must also be trained to be independent. The ability to solve problems is the forerunner of an independent attitude or in other words the ability to solve problems will give birth to an attitude of independence. Meanwhile, independence must be owned by students to face their future.

Sanjaya [5] stated that the advantages of problem solving are as follows: (1) problem solving is a pretty good technique to more understanding the contents of the lesson; (2) problem solving can challenge students' abilities and provide satisfaction to discover new 
knowledge for students; (3) problem solving can improve student learning activities; (4) problem solving can help students on how to transfer their knowledge to understand problems in real life; (5) problem solving can help students to develop their new knowledge and be responsible for the learning they are doing. In addition, problem solving can also encourage self-evaluation of both the result and the learning process; (6) problem solving can show students that each material, basically is a way of thinking and something that must be understood by students is not just learning from the teachers or books; (7) problem solving is considered more fun and liked by students; (8) problem solving can develop students' ability to think critically and develop their ability to adapt to new knowledge; (9) problem solving can provide opportunities for students to apply the knowledge they have in the real world; and (10) problem solving can develop students' interest to learn continuously even if learning in formal education has ended.

\section{Research Method}

This study uses 4D model. Thiangarajan in Trianto [6], this model consist of four main stage such as: 1) define, 2) design, 3) develop, dan 4) dessiminate. In this study, only carried out until the develop stage, while the desseminate stage was not carried out due to limited cost and time.

The steps for the design of the book can be detailed as follows: (1) The define stage, which is aimed at defining the objectives of the course in the curriculum, namely curriculum analysis, concept analysis and student analysis. Curriculum analysis by analyzing learning outcomes based on KKNI. Meanwhile, concept analysis aims to make students master the main concepts of Learning Planning course, while analysis of students to determine students characteristics include age, motivation, knowledge and skills; (2) Design stage, aims to design book based on problem solving and (3) Develop stage aims to produce book based on problem solving that are valid, practical, and effective.

The trial subject of the development of Learning Planning course book based on problem solving is the third semester students of the Economic Education study program in 2019/2020 at Faculty of Economics in Medan State University. The criteria used to choose the location and trial class is the condition of students in accordance with the needs of researchers where the class has never used book based on problem solving.

Data analysis techniques used in this study were (1) validation data analysis. To analyze the validation, the Likert scale is used based on the validation sheet with the steps.: (a) give a score for each item with: very good answers (5), good (4), enough (3), less (2), bad (1) ; (b) add up the total score for each validator for all indicators; (c) providing validator values. For analyzing validity data using the formula:

$$
\text { Validity }=\frac{\text { score e arned }}{\text { maximum skor }} \times 100 \%
$$


Table 1. The Achievement Level of Validity of Book

\begin{tabular}{lll}
\hline No. & Degree of achievement $(\%)$ & Category \\
\hline 1 & $90-100$ & Very valid \\
2 & $80-89$ & Valid \\
3 & $65-79$ & Quite Valid \\
4 & $55-64$ & Less Valid \\
5 & $0-54$ & Very Less Valid \\
\hline
\end{tabular}

The book is said to be valid if has reached a validity level above $80 \%$; and (2) practicality data analysis. To analyze the practicality of book is using questionnaire given to students. The questionnaire was arranged in a Likert scale with a positive category using a modified formula from Lubis.

$$
\text { Degree of achievement }=\frac{\sum \text { each item }}{\sum \text { high score }} \times 100 \%
$$

Table 2. The Level of Practicality of Book

\begin{tabular}{ccl}
\hline No. & Degree of Achievement nnnt(\%) & \multicolumn{1}{c}{ Category } \\
\hline 1 & $90-100$ & Very Practical \\
2 & $80-89$ & Practical \\
3 & $65-79$ & Practical Enough \\
4 & $55-64$ & Less Practical \\
5 & $0-54$ & Very Less Pactical \\
\hline
\end{tabular}

The book is said to be practical if has reached a practical level above $80 \%$.

\section{Results and Discussion}

\section{A. Curriculum Analysis}

In an effort to qualify college graduates in Indonesia, the government has issued Perpres No. 08 year 2012 concerning the Kerangka Kualifikasi Nasional Indonesia (KKNI). The curriculum, which initially refers to the achievement of competencies, refers to learning outcomes. In summary, KKNI consists of nine levels of Indonesian human resources academic qualifications. The implementation of KKNI through 8 stages, namely through the determination of graduation profiles, formulating learning outcomes, formulating the competence of study materials, packaging subjects, preparing curriculum frameworks, preparing lecture plans.

Curriculum analysis is done by analyzing the Competency Standards and Basic Competency in the Learning Planning course. The results of the analysis of competency standards and basic competency become the formulation of learning indicators are as follows: 
1) Understand the nature of learning planning;

2) Understand the learning system design model oriented towards achieving goals;

3) Understand the planning of learning programs;

4) Understand the development of competency as a learning goal;

5) Understand learning strategies;

6) Design learning activities;

7) Understand the development of learning resources and learning media;

8) Understand the techniques for drafting and implementing evaluation of learning outcomes.

\section{B. Concept Analysis}

Concept analysis aims to be the basis for the main concepts that must mastered by the students in the learning process. In the analysis of concepts compiled, identification and formulation of the main concepts that will be arranged in the material in the book based problem solving. Based on the indicators and learning objectives, the main concepts are determined as follows:

1) Definition, importance, benefit, function, learning planning criteria and steps for drafting learning plans;

2) Definition of curriculum based competency, characteristics of curriculum based competency, expected competencies in learning, development and implementation of syllabus, and instructional system design models for achieving competence;

3) The nature of learning planning, learning program development, syllabus, annual program planning, and semester program planning;

4) The nature of learning objectives, the hierarchy of educational and learning objectives, the classification of learning objectives, and the format of designing learning objectives;

5) Understand of learning strategies, understanding of approaches, strategies, methods, techniques and learning models, principles of using learning strategies, and organizing learning strategies;

6) The importance of preparing the lesson plan, the definition and function of the lesson plan, and the components of the lesson plan;

7) Utilization of learning resources, choosing learning resources, learning media, benefits and functions of learning media, use of learning media, classification and types of learning media, characteristics of learning media, and selection and use of learning media

8) The steps of drafting the evaluation of learning outcomes, planning the drafting of learning outcomes evaluation, writing items evaluation of learning outcomes, strengths and weaknesses of the description test, the use of description test, the classification of description test, and techniques for implementing learning outcomes evaluation.

\section{Student Analysis}

Student analysis is conducted to determine student characteristics. The intended student characteristics include age, motivation, background knowledge of students, academic abilities, and social skills. Furthermore, psychological changes that occur such as the search for identity, begin to emerge the aspiration for the future, freedom to do things. The role expected by students in social groups in the community where students interact. This causes problems 
for students, in the form of changing interests, behavior, and values in life. In adolescence, students act without worrying about the risks posed to themselves and others.

\section{1) Design Stage}

At this design stage, researchers design and arrange Learning Planning book based on problem solving. The design stage compiles the product specifications that will be produced. The draft product specifications are as follows:

\section{a. Cover Appearance}

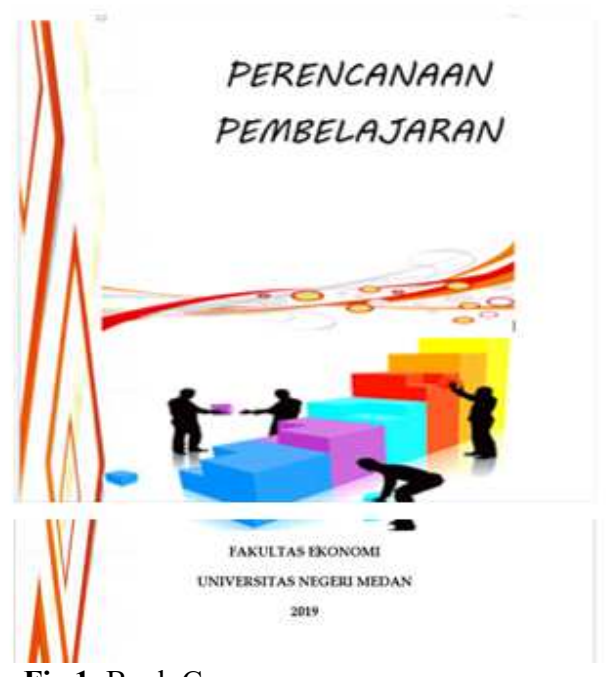

Fig 1. Book Cover

\section{b. Formulation of Learning Objectives}

The formulation of learning objectives is arranged specifically and systematically based on curriculum provision. The formulation of learning objectives starts from setting competency standards, basic competencies and indicators of achieving learning objectives. From the indicators formulated learning objectives that must be mastered by students. Cognitive and psychomotor learning goals are formulated based on competency standards, basic competency and indicators established by the curriculum.

\section{c. Description of Contents of Planing Learning Book}

The description of the material or the content of teaching materials refers to the Kerangka Kualifikasi Nasional Indonesia (KKNI). The curriculum, which initially refers to the achievement of competencies, refers to learning outcomes. In summary, KKNI consists of nine levels of Indonesian human resources academic qualifications.

\section{2) Develop Stage}

The develop stage includes expert validation and book based on problem solving testing to see the validity, practicality and effectiveness of the book developed.

The book that has been develop, then validated by two validators consisting of one expert in the field of Learning Planning and one linguist.

Assessment for practicality is carried out by students. The book is said to be practical, if the book can help students in understanding the material that has been developed. 
The develop stage of Learning Planning book based on problem solving are explained as follows:

\section{a. Expert Validation}

Expert validation consists of 2 phases namely:

(1) Validate the questionnaire validation sheet which will be used by the validator to validate material.

(2) Validation of book using revised questionnaire validation sheet and scoring for assessment of material.

Validate questionnaire validation sheet, useful to determine and revise the needs to be assessed in validating material by the validator. The validation questionnaire validation sheet was revised by two experts according to their respective fields.

At the validation stage, the validation of questionnaire validation sheet contained several sections that were revised. The revision results of each questionnaire validation sheet from experts in general can be seen in the following table:

Table 3. The Revision Results of Validation Sheet

\begin{tabular}{|c|c|}
\hline $\begin{array}{l}\text { No. } \\
(1)\end{array}$ & $\begin{array}{c}\text { Information } \\
\text { (2) } \\
\end{array}$ \\
\hline \multirow[t]{6}{*}{1.} & Material Expert \\
\hline & The validation results are as follows: \\
\hline & $\begin{array}{l}\text { a) The KKNI model is adapted to Medan State University KKNI } \\
\text { curriculum. }\end{array}$ \\
\hline & $\begin{array}{l}\text { b) Learning Planning book based on problem solving have not been fully } \\
\text { integrated in the material. }\end{array}$ \\
\hline & c) Practice questions should more represent learning outcomes. \\
\hline & d) The concept of problem solving book is more sharpened in the material. \\
\hline \multirow[t]{7}{*}{2} & Linguist \\
\hline & $\begin{array}{l}\text { The arrangement of the grid to be developed into question should be according } \\
\text { to the needs (all languages grid are improved) and with the improvements } \\
\text { results of the following: }\end{array}$ \\
\hline & 1. The choice of words appropriate and in accordance with science. \\
\hline & $\begin{array}{l}\text { 2. The structure of sentences and words / terms in accordance with standard } \\
\text { language rules. }\end{array}$ \\
\hline & 3. Simple and clear sentences. \\
\hline & 4. The writing is in accordance with the EYD. \\
\hline & $\begin{array}{l}\text { 5. The use of language and sentence structure in accordance with the level of } \\
\text { ability of students. }\end{array}$ \\
\hline
\end{tabular}

After the validation sheet is revised and declared ready to be used by experts, then the book validation is carried out. The validator of all variables is validated by each expert.

The revision results of book validation for each validator in general can be seen in table 4 below: 
Table 4. The Revision Results of Book

\begin{tabular}{ll}
$\begin{array}{c}\text { No. } \\
\text { (1) }\end{array}$ & \multicolumn{1}{c}{$\begin{array}{c}\text { Information } \\
\text { (2) }\end{array}$} \\
\hline 1 & Material Expert \\
& 1. Add the terms of Medan State University KKNI in book. \\
& 2. Add evaluation term into book. \\
& 3. The exercise questions are designed to meet C4 at the cognitive level, \\
& which is analysis. \\
& Linguist \\
& 1. Improve writing of sentences / paragraphs. \\
& 2. Simplify sentences that are too complex. \\
& 3. Guidelines according to EYD.
\end{tabular}

After the book was revised, then each of validators gave score. Expert in the field of Learning Planning assesses all variables of the concept of material, and linguist evaluates the book language variable.

Table 5. Experts Score

\begin{tabular}{|c|c|c|c|}
\hline No. & RATED ASPECT & \multicolumn{2}{|c|}{ SCORE } \\
\hline \multirow[t]{4}{*}{1} & FORMAT / CONSTRUCT & & \\
\hline & $\begin{array}{l}\text { a. Clarity in material } \\
\text { distribution }\end{array}$ & 4 & - \\
\hline & b. Display and layout & 4 & - \\
\hline & $\begin{array}{l}\text { c. Appropriate type and size of } \\
\text { letters }\end{array}$ & 4 & - \\
\hline \multirow[t]{7}{*}{2} & LANGUAGE & & \\
\hline & $\begin{array}{l}\text { a. The material is delivered } \\
\text { directly by choosing a } \\
\text { simple language }\end{array}$ & - & 4 \\
\hline & $\begin{array}{l}\text { b. The material is delivered in } \\
\text { communicative and } \\
\text { interactive language }\end{array}$ & - & 5 \\
\hline & $\begin{array}{l}\text { c. Writing is done with a good } \\
\text { Indonesian structure }\end{array}$ & - & 4 \\
\hline & $\begin{array}{l}\text { d. Writing is done using good } \\
\text { Indonesian language rules. }\end{array}$ & - & 4 \\
\hline & $\begin{array}{l}\text { e. Writing is done with } \\
\text { effective sentences }\end{array}$ & - & 5 \\
\hline & $\begin{array}{l}\text { f. Writing is done with } \\
\text { efficient sentences }\end{array}$ & - & 4 \\
\hline \multirow[t]{4}{*}{3} & CONTENT & & \\
\hline & a. Having material truth & 5 & - \\
\hline & $\begin{array}{l}\text { b. Having sufficient } \\
\text { competence }\end{array}$ & 4 & - \\
\hline & c. In accordance with the & 4 & - \\
\hline
\end{tabular}




\begin{tabular}{|c|c|c|c|}
\hline \multirow{2}{*}{ No. } & \multirow{2}{*}{ RATED ASPECT } & EXPERT 1 & EXPERT 2 \\
\hline & & \multicolumn{2}{|c|}{ SCORE } \\
\hline & $\begin{array}{l}\text { objectives and learning } \\
\text { outcomes }\end{array}$ & & \\
\hline & d. In accordance with the & & \\
\hline & $\begin{array}{l}\text { implementation of problem- } \\
\text { based learning }\end{array}$ & 3 & - \\
\hline & $\begin{array}{l}\text { e. Having a decent and } \\
\text { complete source of material }\end{array}$ & 5 & - \\
\hline & $\begin{array}{l}\text { f. Content weight according to } \\
\text { time allocation }\end{array}$ & 4 & - \\
\hline & $\begin{array}{l}\text { g. The material presented is in } \\
\text { accordance with stakeholder } \\
\text { needs }\end{array}$ & 5 & - \\
\hline & $\begin{array}{l}\text { h. Equipped with assignments } \\
\text { and evaluation tests that are }\end{array}$ & & \\
\hline & $\begin{array}{l}\text { compatible with the } \\
\text { material, objectives, and } \\
\text { learning outcomes }\end{array}$ & 4 & - \\
\hline
\end{tabular}

The results of data analysis of the validator assessment scores can be seen in table 6 below.

Table 6. Validator Assessment Results

\begin{tabular}{clcc}
\hline No. & Variable & Degree of achievement $\mathbf{( \% )}$ & Category \\
\hline 1 & Content & 84,44 & Valid \\
2 & Construct & 80 & Valid \\
3 & Language & 86,66 & Valid \\
\hline Average & $\mathbf{8 3 , 7}$ & Valid \\
\hline
\end{tabular}

The results of the validator assessment score analysis in table 6 consist of 4 variables, as follows: 1) contents with an achievement level of $84.44 \%$ are categorized valid, 2) constructs with an achievement level of $80 \%$ are categorized valid, 3) languages with an achievement level of $86.66 \%$ categorized as valid. In general, the average validity of Learning Planning book with a degree of achievement of $83.7 \%$ and book can be categorized as valid.

The comparison of degree of achievement of validation results of each variable by the validators for more details can be observed in the following:

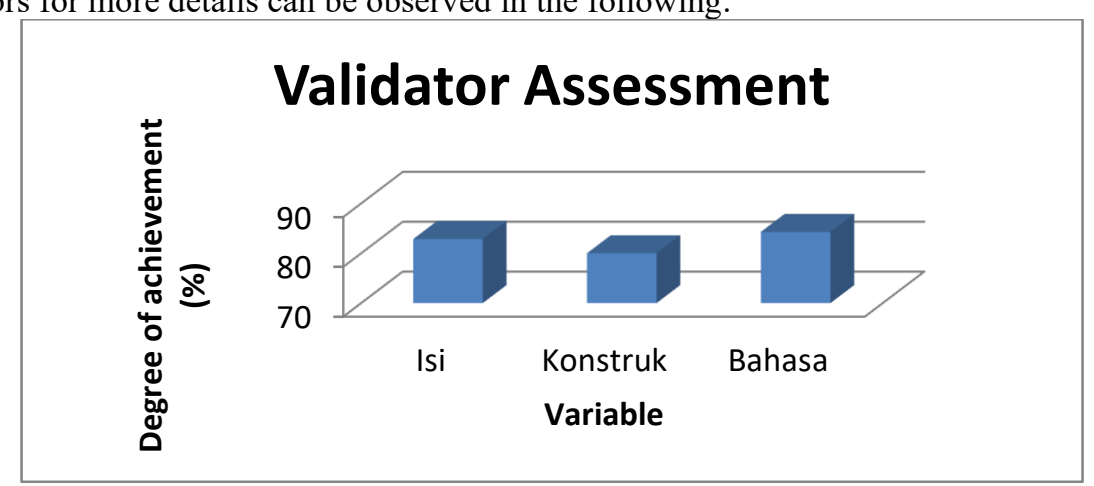

Fig 2. The Validity Results of Book 


\section{b. Book Trial}

A limited trial of book based on problem solving was conducted in class $\mathrm{C}$ of the Economic Education Study Program, Faculty of Economics, Medan State University. The trial serves to assess the practicality of book by students as users of teaching material. The effectiveness of teaching material can be seen from the activities of students during the learning process by using book. In addition, also evaluation to see student learning outcomes.

\section{c. Practicality of Book}

The practicality assessment of book is assessed by students as user / stakeholder of Learning Planning book. The practicality of Learning Planning book based on problem solving is assessed by students of Class C of Economic Education Study Program who are also trial subject of book. After practicality assessment of Learning Planning book based on problem solving by students, then data analysis is performed. The results of data analysis can be seen in table 7 .

Table 7. Students Practicality Result

\begin{tabular}{clcc}
\hline Variables & Level of Achievement (\%) & Category \\
\hline 1 & Learnability & 83,52 & Practical \\
2 & Efficiency & 80,71 & Practical \\
3 & Effectiveness of time & 80,48 & Practical \\
& Average & $\mathbf{8 1 , 5 7}$ & Praktis \\
\hline
\end{tabular}

The analysis results of practicality assessment data by Class $\mathrm{C}$ students of Economic Education Study Program who are also the trial subject of Learning Planning book based on problem solving which consists of three variables, namely 1) Learnability with an achievement level of $83.52 \%$ and categorized as practical for users, 2) Efficiency with an achievement level of $80.71 \%$ and categorized as practical use in the learning process, and 3 ) effectiveness of time with an achievement level of $80.48 \%$ and categorized can make time effective in the learning process. The practicality value of teaching materials by students with level of achievement is an average of $81.57 \%$ and can be categorized as practical.

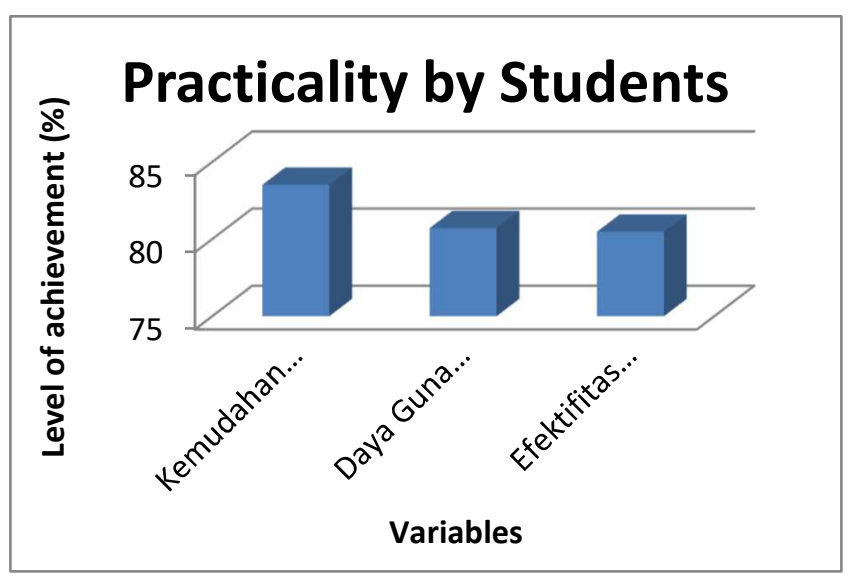

Fig 3. Students Practicality Value 


\section{Discussion}

According to Depdiknas [3] that a teaching material is said to be good and easy for students to understand if the material in one unit is intact according to the users' ability (Self Contained). According to Nieveen, the validity of a product can be related to two things: 1) whether the results of development are based on rational of strong theoretical, and 2) whether there is internal consistency. In addition, the determination of validity is determined by expert or people who understand the learning material.

The presentation of teaching materials is according to students' abilities with a value of $83.7 \%$ is considered valid. The description of the content / teaching materials is arranged systematically so that users can easily understand the teaching materials. Teaching materials are formulated in a clear learning unit starting from the presentation of materials, instructions for use, and evaluation tools. Presentation of the formulation of teaching materials is in accordance with the level of students' abilities.

Learnability of teaching materials in the learning process with a value of $83.52 \%$ categorized as practical for users. Because teaching materials have instructions for use, language is appropriate to the characteristics of students, can be used individually and exercises can help lecturers in directing students to understand concepts. Books are designed to facilitate lecturers in guiding students in the learning process.

According to Depdiknas [3], one of the objectives of teaching materials is to clarify and facilitate the presentation of messages so they are not too verbal. According to Sanjaya [5], one of the objectives of teaching materials is to increase the effectiveness and efficiency of achieving educational and teaching goals. Efficiency with a value of $80.71 \%$ is categorized as practical because book can help students in explaining concepts. A practical book is expected to be able to help lecturers direct students in the learning process.

According to Depdiknas [3], a good book can overcome the limitations of time, space, and sense power, for the teacher/supervisor in the learning process. Teaching materials that are practical in the effectiveness of time with a value of $80.48 \%$ categorized as practical. Teaching materials developed are practical used by lecturers to guide students in the learning process. Thus, lecturers can utilize minimal time with maximum results.

Based on observations observed by one observer, generally students are active in the learning process. This shows that the book based on problem solving are practical used in the learning process.

\section{Conclusion}

From the results of research and discussion above, this study produced several conclusions as follows:

1) A teaching book based on problem solving has been produced that is valid and practical.

2) The value of the validity of Learning Planning book based on problem solving with content, construct, and language variables obtained an average of $83.7 \%$ and the book can be categorized valid.

3) The practicality value of Learning Planning book based on problem solving by students is $81.57 \%$ and teaching book can be categorized as practical in the learning process. 
Based on the conclusions above, this study produces the following recommendations:

1) This study has practical recommendation for lecturers to design book based on problem solving in other subjects because the use of problem solving in delivering learning material can stimulate students' creative thinking abilities related to solve the material being taught.

2) For stakeholders, it can review instructional material that has been developed, revalidated, and further developed so that it can be generally accepted and used in a standard both at the study program and faculty level.

\section{References}

[1] Direktorat Jendral Pendidikan Tinggi. Jakarta: Direktorat Jendral Pendidikan Tinggi. (2014).

[2] Prastowo, Andi. Panduan Kreatif Membuat Bahan Ajar Inovatif. Jogjakarta: Diva Press. (2015).

[3] Badan Standar Nasional Pendidikan. Standar Penilaian Bahan Ajar. Jakarta: Badan Standar Nasional Pendidikan. (2007).

[4] A.M., Sardiman. Interaksi dan Motivasi Belajar Mengajar. Raja Grafindo Persada: Jakarta. (2008).

[5] Sanjaya. Model Problem Solving. Jakarta: Sanata Dharma. (2016).

[6] Trianto. Mendesain Model Pembelajaran Inovatis-Progresif. Jakarta: Kencana. (2012).

[7] Miharja, Fuad Jaya. Pengembangan Modul Anatomi Fisiologi Manusia Dengan model Pembelajaran Berbasis Masalah Untuk Meningkatkan Kompetensi Mahasiswa Program Studi Pendidikan Biologi. Prosiding Seminar Nasional Pendidikan Biologi 2015 Malang. (2015).

[8] Sugiyono. Metode Penelitian Kuantitatif, Kualitatif, dan R\&D. Bandung: Alfabeta. (2013).

[9] Slamet, Margono. Memantapkan Posisi dan Miningkatkan Peran Penyuluhan Pengembangan dalam Pembangunan. Dalam Proses dingeminar IPB Bogor: Pemberdayaan Sumber Daya Manusia Menuju Terwujudnya Masyarakat Madan. Pustas Wira Usaha Muda. (2000).

[10] Soekartawi. Agribisnis Teori dan Aplikasinya. Jakarta. PT Raja Grafindo Persada. (2003).

[11] Sukirno, Sadono. Makro Ekonomi Modren. Penerit PT. Raja Grafindo Perkasa, Jakarta. (2000).

[12] Sukirno, Sadono, Makroe konomi : Teori Pengantar. Jakarta : PT. Raja Grafindo Persada. (2013).

[13] Utami, Jam hari, dan Suhatmini Hardyastuti. El Nino, La Nina dan Penawaran Pangan di Jawa, Indonesia. Jurnal Ekonomi Pembangunan. Vol. 12:2, hlm.257-271. (2011).

[14] Werf, H. Ilmu Manajemen Pemerintahan. Jakarta. (1997).

[15] Yamin, Sofyan \& Heri Kurniawan. SPSS Complete, Jakarta: Selembah Empat. (2009). 